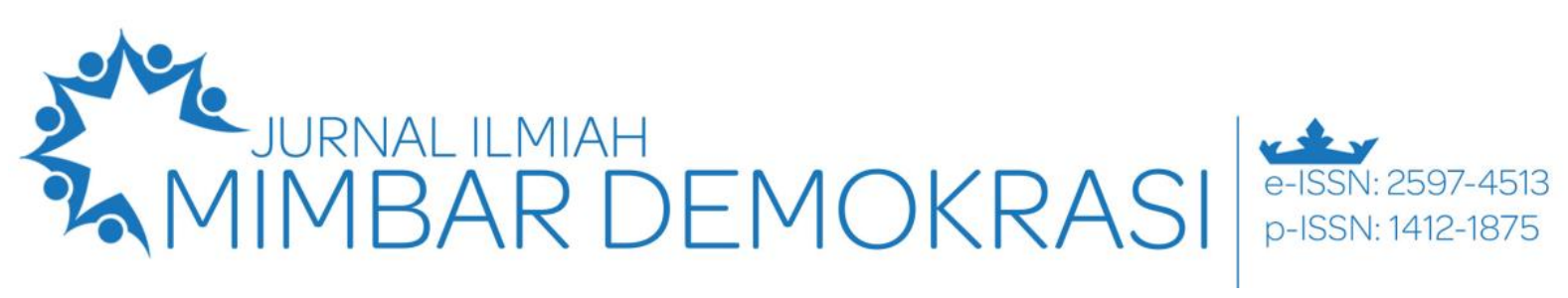

Vol. 20 No. 2 April 2021 | Hal. 52 - 60

\title{
The student legal awareness against the hazards of smoking for health in school
}

\section{Dwi Afrimetty Timoera ${ }^{1}$, Asep Rudi Casmana ${ }^{2}$, Iqbal Syafrudin ${ }^{3}$, Yasnita ${ }^{4}$}

Universitas Negeri Jakarta, Indonesia

${ }^{1}$ dwiafrimetty@unj.ac.id*; ${ }^{2}$ aseprudi@unj.ac.id; ${ }^{3}$ syafrudin@unj.ac.id; ${ }^{4}$ yasnita@unj.ac.id

*Corresponding Author

\begin{tabular}{l}
\hline Information \\
\hline Received: \\
12-11-2020 \\
Accepted: \\
15 -01-2021
\end{tabular}

Keywords:

Awareness

Law

Smoking

Student

\begin{abstract}
The purpose of this study was to find out about (1) The level of legal awareness regarding the dangers of smoking for the health of junior and senior high school students (2) Strategies that need to be done to increase legal awareness regarding the dangers of smoking for the health of junior and senior high school students in the capital city of Jakarta. This research is a research using descriptive qualitative. The method of collecting data is through online interviews. Respondents in this study were 13 civic education teachers at the junior and senior high school levels and 10 junior high school students. The data analysis technique uses data reduction, data display and data verification. The results showed (1) The level of legal awareness of students against the dangers of smoking was very good, this can be seen from the majority of students obeying the smoking prohibition rules in schools. Even so, there are still some unscrupulous students who are caught smoking and bringing vapes (e-cigarettes) to school. (2) The strategy that has been carried out by teachers in schools to increase the legal awareness of students regarding the dangers of smoking for the health of junior high and high school students in the capital city of Jakarta is by increasing legal knowledge and awareness of students through repressive, preventive and maximally repressive through learning civic education.
\end{abstract}

Keywords:

Kesadaran hukum

Merokok

Siswa

\begin{abstract}
ABSTRAK
Kesadaran hukum siswa sekolah dasar terhadap bahaya merokok bagi kesehatan. Tujuan penelitian ini adalah untuk mengetahui tentang (1) Tingkat kesadaran hukum terkait bahaya merokok bagi kesehatan siswa-siswi SMP dan SMA di DKI Jakarta dan Banten; (2) Strategi yang perlu dilakukan untuk meningkatkan kesadaran hukum terkait bahaya merokok bagi kesehatan siswa-siswi SMP dan SMA di DKI Jakarta dan Banten. Penelitian ini adalah penelitian dengan menggunakan kualitatif deskriptif. Metode pengumpulan data melalui wawancara dan analisis datanya menggunakan reduksi data, display data dan verifikasi data. Hasil penelitian menunjukkan (1) Tingkat kesadaran hukum peserta didik tergolong cukup baik, hal ini terlihat dari mayoritas siswa-siswi mematuhi aturan larangan merokok di sekolah. Meskipun demikian, masih ada beberapa oknum siswa yang ketahuan merokok dan membawa vape (rokok elektrik) ke sekolah. (2) Strategi yang telah dilakukan oleh para guru di sekolah untuk meningkatkan kesadaran hukum peserta didik terkait bahaya merokok bagi kesehatan siswa-siswi SMP dan SMA di DKI Jakarta dan Banten adalah dengan cara meningkatkan pengetahuan dan kesadaran hukum para siswa-siswi melalui upaya preemtif, preventif dan represif secara maksimal.
\end{abstract}

Copyright $(\mathcal{C} 2021$ (Dwi Afrimetty Timoera, Asep Rudi Casmana, Iqbal Syafrudin, Yasnita). All Right Reserved

How to Cite: Timoera, D.A., Casmana, A.R., Syafrudin, I., \& Yasnita. (2021). The student legal awareness against the hazards of smoking for health in school. Jurnal Ilmiah Mimbar Demokrasi, 20(2), 52-60. DOI: 10.21009/jimd.v20i2.17979

This work is licensed under a Creative Commons Attribution-ShareAlike 4.0 International License. Allows readers to read, download, copy, distribute, print, search, or link to the full texts of its articles and allow readers to use them for any other lanful purpose. The journal bold the copyright. 


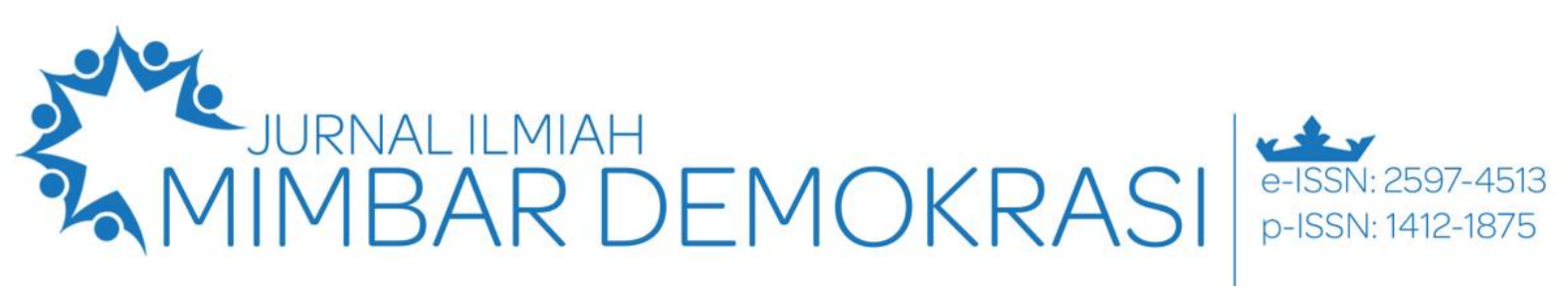

Vol. 20 No. 2 April 2021 | Hal. 52 - 60

\section{Introduction}

Awareness of the law in society cannot be measured from the economic level of the community itself or the level of education (Xinghua, 2009). Logically, someone who has a high level of education understands the applicable rules, so the level of violations they commit is very low. However, in reality, many people who come from higher education backgrounds still commit mistakes and violations due to a lack of awareness of the law (Woods \& Pratt, 2005). Meanwhile, in terms of income or financially, it is not certain that the people who make mistakes are those who come from poor or low-income families. Even those who are economically to the upper middle class actually make mistakes due to a lack of awareness of the law (Mohamadinejad \& Mirsafian, 2015).

When viewed from the correctional institution today, the prisoners in the remand center are in fact several officials or people who have a high level of education and also have a high economic income. For example, the lowest echelon officials to high-level officials, members of the Regional People's Representative Assembly, Provincial Regional People's Representative Assembly, member of People's Representative Council, Regents, Governors to the level of ministerial positions. This is not a reflection that legal awareness can be seen at the level of education and financial status. However, according to some experts, legal awareness depends or is heavily influenced by the exemplary leadership and the surrounding environment (Kovalchuk, 2015; Izabal, 1995). Therefore, there needs to be a way to instill an attitude of legal awareness in society.

Embedding legal awareness in society must be carried out by all parties, so that legal order can run smoothly (Guth \& Ashford, 2014; Chernaya, 2018). In addition, laws were also formed to regulate norms and human life, of course, so as not to harm one another. Even the law is also used to regulate what people can and cannot do (Pevtsova, Sapogov, Timofeev, \& Knyazeva, 2016).

The application of the law will not be enforced if there is no awareness to obey it (Santos, et al., 2017). Legal awareness must be based on knowledge of what law is. If someone does not know what law is, then of course he cannot carry out the law properly. He must know that law is important for society because it protects people from lawlessness.

Next is awareness about legal obligations towards others. It is also important because it will enable the law to work properly. When a person knows what he can and cannot do to others, and is aware that there will be a reward for everything he does, good or bad, they will automatically have a sense of the law.

One way to be able to instill legal awareness is through the educational process. Everything about the knowledge, understanding, legal awareness of others, and accepting the law, must be conveyed in an appropriate manner. Education is one way to convey it. This of course can be started from the family environment, school and then later to the wider community.

The student legal awareness should be taught in school. It is because the school is the place to educate legal awareness for the student. Civic Education is one of the school's subject that can taught students with the understanding of law in school (Ernaningsih \& Anomeisa, 2019). In this subject, there are a lot of content that can make students to understand regarding the legal awareness.

No smoking in school is one of the rule imposed by every educational institution in Indonesia (Ernaningsih \& Anomeisa, 2019). In Jakarta, most of the school ask the student not to smoke since the hazard of smoking towards health (Rosamarlina \& Dianiati 2010). However, there are a lot of cases which revealed that students are still undertaking to smoke in school, although it has been written on the school rule that smoking is totally banned (Risdianto, 2018). As such, there is a need for Pancasila and Civic Education teacher to educate students more about not to smoke in school.

Imposing a rule to ban smoking from the school has a wide range of positive impacts for students itself. Students can be healthier and be better for the future. Therefore, it is better that smoking in school should be banned.

Based on the background of the above problems, this study will examine and focus on increasing legal awareness for junior high and high school students in'The capital city of Jakarta regarding increasing legal awareness regarding the dangers of smoking to health. 


\section{Methods}

This research uses descriptive qualitative research. Bogdan and Tylor define qualitative research as a research procedure that produces descriptive data in the form of written or spoken words from people or observed behaviour (Sugiyono, 2013). The descriptive qualitative method adjusts the opinion between the researcher and the informant. The choice of this method was done because the analysis could not be in the form of numbers and the researcher would rather describe all phenomena that exist in society clearly.

This research was carried out in stages according to a predetermined schedule, namely to obtain complete data. The data that has been obtained from the interview process are then presented in the form of descriptions using words that are easy to understand and understand.

Primary data sources are data taken directly by researchers to the source without any intermediaries by digging up the original sources directly through respondents (Ichwan, Salim, \& Srimulyani, 2020). Primary data sources were obtained through online or online interviews due to limited space due to the Covid-19 pandemic. The primary data sources in this study were civic education teachers in The capital city of Jakarta area.

Secondary sources are sources taken from other sources that are not obtained from primary sources (Mujis, 2010). Secondary data sources were obtained through library research with the help of print media and internet media. Secondary data sources are indirect data sources that can provide additional data and strengthen research data. In this study, secondary data sources are literature, articles, magazines, journals, and sites on the internet relating to research.

The data collection technique is a method used to obtain the data needed in research. In this research, the technique used is the interview technique. An interview is a conversation with a specific purpose. The conversation was carried out by two parties, namely the interviewer (interviewer) who asked the question and the interviewer (interview) who gave the answer to the question (Davies et al., 2020).

The main characteristic of the interview is direct, face-to-face contact between information seekers and information sources. In the interview various kinds of questions have been prepared but various other questions arise when researching. Through this interview, the researcher digs up the data, information, and description framework from the research subjects.

The interview technique used was guided free interview, meaning that the questions asked were not fixed on the interview guide and could be deepened or developed according to the situation and conditions in the field. However, interviews were conducted online or online via the whatsapp call media. Online interviews were conducted with 13 civic education teachers and 10 junior high school students in The capital city of Jakarta.

Data analysis is the process of arranging data sequences, organizing them into a pattern, category and a basic description so that themes can be found and work hypotheses can be formulated as suggested by the data (Pashby, da Costa, Stein, \& Andreotti, 2020). After the overall data has been collected, the next step for the researcher to analyze the data is to draw a conclusion. (Cohen, et.al., 2007)

The research technique used in this research is analysis using an interactive model. In this model, there are 3 (three) components of the analysis, namely data reduction, data presentation and conclusion drawing.

\section{Results and Discussions}

\section{Results}

\section{a. Legal Knowledge Regarding the Dangers of Smoking}

Legal knowledge is knowledge possessed by a person regarding any behavior that is regulated by law. Based on the results of interviews conducted by researchers with civic education for junior high school and senior high school teachers who intensely disseminate information to junior and senior high school students inThe capital city of Jakarta, it turns out that the majority of students' knowledge of the Regulation of the Minister of Education and Culture of the Republic of Indonesia Number 64 of 2015 regarding the prohibition smoking in schools and the dangers of smoking to health are quite high.

“... In our school, through civic education subjects, we always socialize school rules, whether they are allowed or not. Regarding smoking, it's prohibited and I always socialize it on civic education lessons. " (interview, teacher, August 2020) 


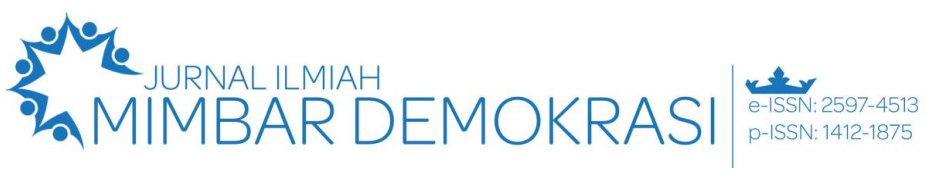

\section{Vol. 20 No. 2 Tahun 2021 | Hal. 52 - 60}

Through information from the civic education teacher, knowledge of legal awareness was obtained through socialization that was carried out during the civic education lesson.

The reason is, from the interviews the researchers conducted with teachers in The capital city of Jakarta, all students were aware of the prohibition through various kinds of socialization programs carried out in schools. From the results of interviews with several civic education for junior and senior high school teachers in The capital city of Jakarta, students always regularly receive socialization regarding the existing prohibitions in schools, especially regarding smoking bans.

In addition, students also get a lot of information about the dangers of smoking for health through socialization activities that are often included in the subjects taught by the teacher. Thus, the socialization and provision of knowledge seems to have a positive effect on the level of knowledge of students on smoking bans.

"I always remember that my
teacher always said that if I
violated school rules, I
would be threatened with
notgraduating or even being
expelled from school. So that
I dare not break school
rules, including smoking
"(interview, student, August
2020)

Based on the information from one of the students, it was said that they were very afraid that they would not go to class or be expelled from school, so they did not dare to be able to act against school rules.

\section{b. Students' Legal Understanding of the Prohibition and Dangers of Smoking}

Legal awareness can be seen from the indicator of legal understanding when someone has an understanding of certain legal rules. In other words, someone understands a number of information regarding the content of certain legal regulations (Delima \& Adi, 2020).

Based on interviews that researchers have conducted with civic education teachers for junior and senior high school in The capital city of Jakarta, students' understanding of the smoking ban in schools is classified as good. This can be seen from the answers to the interviews of the teachers regarding the compliance of students in complying with the no smoking regulations in several schools.
According to the teachers who were respondents, the students in their schools mostly understood the smoking ban in schools and almost all respondents answered that the students understood the rules.

"One of the punishments
students receive when
smoking in school is being
called by their parents to
school. So it becomes a very
embarrassing thing,
because parents always get
angry too (interview,
student, August 2020)

In order to understand the concept of law and how the law applies, schools apply the rule of law and implement it. Schools strictly take action against students who violate legal rules, so that it is hoped that this can make a positive thing and make these students stop smoking. The punishment of summoning their parents is one of the things that junior high school students are very afraid of, because if their parents know that their students smoke, they will get double punishment, both at school and at home.

"If I am caught smoking
many times at school, and
my points are maximal, then
I can also be expelled from
school and returned to my
parents". (interview,
student, August 2020)

In addition to contacting parents, smoking punishment can also be a thing that results in the student being returned to the parent, because with the accumulated points the student gets, and if the student does this repeatedly, the student can be returned to the parent.

This punishment can be something that students fear, if they are given threats to be expelled from school, because this can be a bad label for these students. So that by doing so, these students try to continue to improve their understanding and avoid things related to violating school rules.

\section{c. The Legal Attitude of Students Against the Prohibition and Dangers of Smoking}

From the indicators, the legal attitude applies when a person has a tendency to assess the law as something that is beneficial to him if the law is obeyed or becomes something that is not profitable if the law is not obeyed (Delima \& Adi, 2020). 
From the results of interviews conducted by researchers, it was clear that many students (junior and senior high school students) were obeying the smoking ban in schools by not smoking in schools and also not bringing cigarettes to school. However, there were some respondents who said that they did not know whether there were students who smoked outside the school environment.

"With the socialization of legal rules and actions given by schools by punishing students who smoke, most students follow school rules about the dangers of smoking, although there are also some students who still violate" (interview, teacher, August, 2020)

Students' attitudes mostly change when students know the applicable legal rules, this is because they already understand and understand some of the rules about the laws that apply in school, especially regarding smoking rules. But even so, schools still cannot monitor the overall way these students behave in the community or outside of school, because they can also smoke outside school hours.

\section{d. The Legal Behavior of Students Against the Prohibition and Dangers of Smoking}

This indicator of legal behavior is an indicator of legal awareness of the highest level because it is an act of a person in complying with legal regulations that apply in society or in any environment he is in. So that legal behavior really becomes a reflection of people's legal awareness (Delima \& Adi, 2020; Ernis, 2018).

From the results of interviews conducted by researchers, the majority of students (junior and senior high school students) in The capital city of Jakarta. Most of them comply with the rules that apply in schools, especially regarding smoking prohibition in the school environment. This is because most of the violations that occur at school are only cases of late attendance and bullying between students.

Even so, according to the respondents there were also some unscrupulous students who violated smoking rules. Smoking violations that occur in these schools are not many because only 2 or 3 students do so. Even then, they do not smoke in the school environment, but instead they smoke in a shop near the school. The reason they smoke is only because they are curious about cigarettes or just to be stylish in front of other people. The harshest punishment ever given to those who violate it is expelled from school.
In addition, there are also students who bring vapes (a type of electric cigarette) to the school environment. This is known when there are some students who report to the teacher regarding their friends who bring vapes (e-cigarettes) to school. Furthermore, students caught carrying the vape (electric cigarette) to school are immediately handled by the school. Then the punishments given to these unscrupulous students are in the form of summoning parents to school and suspension.

With the existence of several students reporting their friends to the teacher when they committed violations related to smoking, it can be concluded that legal awareness regarding the dangers of smoking is actually owned by students at school. It's just that, there are still some unscrupulous students who commit violations.

They also commit violations related to smoking on the pretext of simply being curious or just wanting to appear stylish in front of their friends and not smoke because they are addicted. Here it can be seen that the legal awareness of students regarding the prohibition and dangers of smoking is quite good even though there are still some unscrupulous students who commit smoking violations.

\section{e. Legal awareness raising strategy}

As the results of research through interviews with several civic education teachers for junior and senior high school in the capital city of Jakarta, that in increasing the awareness and legal compliance of students regarding the smoking ban in the school environment and the effects or dangers of smoking on health, the efforts made will be maximized. In this case, there are three efforts that can be made by the school to increase the legal awareness of students regarding the smoking ban and the dangers of smoking to health. The three efforts are preemptive, preventive, and repressive measures.

The first step is the initial step, namely through preemptive efforts. Pre-emptive efforts are efforts made in various ways of socializing. One of the most commonly used measures is through socialization or counseling on smoking bans in school environments in accordance with the Regulation of the Minister of Education and Culture of the Republic of Indonesia Number 64 of 2015 regarding smoking bans in schools and the dangers of smoking to health. This material is usually delivered by inserting it into subjects in the Teaching and Learning Activities (KBM) process in schools. 


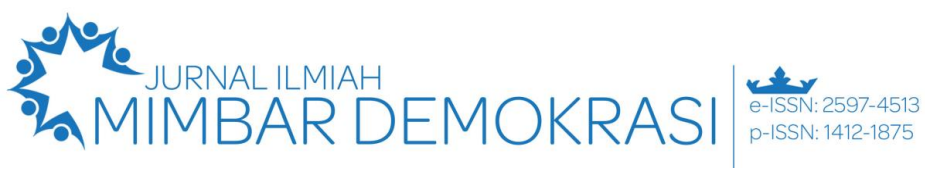

\section{Vol. 20 No. 2 Tahun 2021 | Hal. 52 - 60}

For example, it is more included in the civic education material or included in the material PAI (Islamic Religious Education). One of them is a combination of classroom learning through giving examples related to violations that usually occur among youth. For example in the 8 th grade material, related to the youth oath. The teacher analyzes the case examples of youth leaders in the past and today. Then the teacher invites students to analyze the causes of youth in ancient times fighting for independence, whereas youth today tend to smoke frequently, do brawls, consume drugs, get drunk, and get caught in promiscuity.

In addition, schools always socialize school rules by creating a "Student Manual" which contains all school rules and regulations. The book was distributed to students and also socialized during the MPLS (Introduction to School Environment), PLS (Introduction to School Environment) or MOS (Student Orientation Period) program. Not only that, the rules that apply in the school environment are also usually provided on the school website in the form of pdf data which can be downloaded by students.

Even the rules of discipline that apply in schools are often conveyed at the morning roll call before teaching and learning activities (KBM) begin at school. In addition, the school is also assisted by socialization events organized by the $\mathrm{BNN}$ regarding the dangers of smoking and the dangers of drugs (NAPZA). Not only that, teachers and parents also play an important role in teaching students by calling their parents when a child violates.

The teacher also provides a good role model for students by not smoking in school. There are even several rewards and punishments that apply to students in schools related to the legal regulations that apply in schools. For example, the OSIS which has the Best Student program by giving appreciation to students regarding their exemplary terms of not smoking, honesty, obedience, getting to class on time, etc. The assessment of this is usually carried out by the Counseling Guidance teachers and also the homeroom teacher. Related to this, this effort needs to be improved both in terms of quality and quantity, especially for the students (junior high and high school students) themselves.

Then the second attempt, a way to increase students' legal awareness regarding smoking bans in the school environment and related to the dangers to health is carried out through preventive efforts. This preventive effort is carried out in the form of preventive measures before the occurrence of violations in schools and especially to avoid the impact of these violations. According to the accounts of the respondents, this method is very effective in order to increase students' legal awareness regarding smoking prohibition and the dangers of smoking to health.

This is done by checking students every day regarding attributes or uniforms, attendance, raids on luggage, and so on. This method is done with the intention that students always remember the legal rules that apply at school and also follow the rules set by the school. In this case, it turns out that this method is very effective in increasing legal awareness among junior and senior high school students. The reason is, from the results of the checking, the number of violations found was very small.

Furthermore, the third effort is repressive measures in the form of law enforcement in the form of actions after the occurrence of violations. The repressive efforts that were carried out were aimed at providing a deterrent effect on the students who violates the smoking ban in the school environment. According to the respondents, this repressive effort was carried out by providing a punishment that was severe enough to make students (junior high school and senior high school students) feel afraid to commit these violations.

The trick is that these students are directly handled by the school and immediately given a penalty because smoking is a serious violation at school. The punishments given are in the form of calling parents to school, giving SP or warning letters (in this case, there are three levels of warning letters, for students who are caught smoking, they will immediately get SP3), and suspension of students who violate. In addition, the school's heaviest repressive effort was to expel students who violated these regulations from school. So that students who violate these are no longer entitled to education at schools that stipulate these rules.

\section{Discussions}

Legal awareness can be interpreted as the awareness of a person or a group of people to the rules or laws that apply. Legal awareness is needed by a society. This is intended so that order, peace, tranquility and justice can be realized in the interaction between people. Without having a high legal awareness, this goal will be very difficult to achieve (Tagel, 2013). 
Legal awareness can be taught in school, especially in the civic education subject. It is because the subject encourages students to think critically about what the students should act in regard to the rule imposed by the school.

This part revealed on how the school educate students to be understand of avoiding smoking in the school are since it has negative impact towards themselves. It can be said that the legal awareness of students in school is based on how teacher educate them.

The legal awareness of students regarding the prohibition and dangers of smoking is quite good even though there are still some unscrupulous students who commit smoking violations. Smoking violations that occur in these schools are not many because only 2 or 3 students do so. Even then, they do not smoke in the school environment, but instead they smoke in a shop near the school.

The reason they smoke is only because they are curious about cigarettes or just to be stylish in front of other people. The harshest punishment ever given to those who violate it is expelled from school. In addition, there are also students who bring vapes (e-cigarettes) to the school environment.

This is known when there are some students who report to the teacher regarding their friends who bring vapes (e-cigarettes) to school. Furthermore, students caught carrying the vape (electric cigarette) to school are immediately handled by the school. Then the punishments given to these unscrupulous students are in the form of summoning parents to school and suspension.

Then the strategy to increase students' legal awareness of the dangers of smoking can be done with 3 efforts, namely:

\section{a. Preemptive Efforts}

Preemptive efforts are efforts made in various ways of socializing. One of the most commonly used measures is through outreach or counseling about smoking bans in the school environment. This is in accordance with the Regulation of the Minister of Education and Culture of the Republic of Indonesia Number 64 of 2015 regarding the prohibition of smoking in schools and the dangers of smoking for health. This material is usually delivered by inserting it into subjects in the Teaching and Learning Activities (KBM) process in schools.

\section{b. Preventive Efforts}

This effort is made in the form of preventive measures before the occurrence of violations in schools and especially to avoid the impact of these violations. According to the accounts of the respondents, this method is very effective in order to increase students' legal awareness regarding smoking prohibition and the dangers of smoking to health.

This is done by checking students every day regarding attributes or uniforms, attendance, raiding luggage, and so on. This method is done with the intention that students always remember the legal rules that apply at school and also follow the rules set by the school.

\section{c. Repressive Efforts}

This effort is carried out in the form of law enforcement in the form of actions after the occurrence of violations. This effort aims to provide a deterrent effect on students who violate the smoking ban in the school environment. According to the respondents, this repressive effort was carried out by providing a punishment that was severe enough to make students (junior high school and senior high school students) feel afraid to commit these violations.

The trick is that these students are directly handled by the school and immediately given a penalty because smoking is a serious violation at school. The punishments given are in the form of calling parents to school, giving SP or warning letters (in this case, there are three levels of warning letters, for students who are caught smoking, they will immediately get SP3), to giving suspension of students who violate.

\section{Conclusion}

Based on the results of the research description, two conclusions can be drawn as follows. The first conclusion is that the level of legal awareness of junior high and high school students in Jakarta about the dangers of smoking for health is quite good even though there are still some unscrupulous students who commit smoking violations.

This can be seen from the majority of junior high and high school students in The capital city of Jakarta to comply with regulations regarding smoking prohibition in the school environment. In addition, with some students reporting their friends to the teacher when they committed violations related to smoking, it can be concluded that the students in school already have legal awareness regarding the dangers of smoking. 


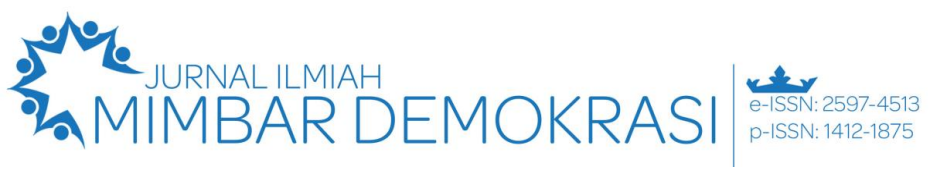

\section{Vol. 20 No. 2 Tahun 2021 | Hal. 52 - 60}

The second conclusion, the strategy that can be taken by schools to increase legal awareness regarding the dangers of smoking for the health of junior and senior high school students is by increasing legal knowledge and awareness of junior and senior high school students through pre-emptive, preventive and maximally repressive efforts .

Therefore, students, especially junior and senior high school students, can better understand, realize, and raise legal awareness regarding the dangers of smoking to health in order to create orderly conditions and be aware of the dangers of smoking at an early age which should still be very productive.

To optimize the role of schools in an effort to increase legal awareness regarding the dangers of smoking for health among junior high and high school students in The capital city of Jakarta, it is necessary to carry out further activities involving agencies at the sub-district or district level so that there is continuous cross-sectoral cooperation. From the research conclusion, the following suggestions are proposed:

a. It is necessary to intensify dissemination (information dissemination activities) which are carried out on a circuitous basis from school to school.

b. The need for dissemination to teachers of various subjects by involving parents or committees, and the dissemination should be done regularly or scheduled every year or per semester.

c. Fulfilling the facilities, infrastructure for information and technology related to legal knowledge and awareness of the dangers of smoking to health for junior high and high school students so as not to cause new problems in the future.

\section{Reference}

Chernaya, A. V. (2018). Children`s Rights Concept in Modern Social and Humanitarian Discourse. Journal of Social Studies Education Research, 9(4), 140-167.

Cohen, L., Manion, L., \& Morrison, L. (2007). Research methods in education (7th edition). Routledge.

Davies, I., Evans, M., Fülöp, M., Kiwan, D., Peterson, A., \& Sim, J. (2020). Youth activism, engagement and the development of new civic learning spaces issues about impact. Journal of Social Science Education, 19(2), 96-105. https://doi.org/10.4119/jsse-3440
Delima , F. P., \& Adi, A. S. (2020). Tingkat Kesadaran Hukum Pengguna Jasa Layanan Parkir Terhadap Penyelenggaraan Parkir Tepi Jalan Umum (Tju) Zona Di Kawasan Pasar Blauran Surabaya. Kajian Moral dan Kewarganegaraan, 8(2), 138-152.

Ernaningsih, D., \& Anomeisa, A. B. (2019). Peran Guru Pkn Dalam Meningkatkan Kesadaran Hukum Siswa Terhadap Tata Tertib Sekolah. BIRUNIMATIKA, 4(1), 013020.

Ernis, Y. (2018). Implikasi Penyuluhan Hukum Langsung Terhadap Peningkatan Kesadaran Hukum Masyarakat. Jurnal Penelitian Hukum DE JURE, 18(4), 477-496.

Guth, J., \& Ashford, C. (2014). The Legal Education and Training Review: regulating socio-legal and liberal legal education? The Law Teacher, 48(1), 5-19.

Ichwan, M. N., Salim, A., \& Srimulyani, E. (2020). Islam and Dormant Citizenship: Soft Religious Ethno-Nationalism and Minorities in Aceh, Indonesia. Islam and Christian-Muslim Relations, $\quad 0(0), \quad 1-26$. https://doi.org/10.1080/09596410.2020.178 0407

Izabal, M. L. (1995). Women's legal knowledge: A case study of Mexican urban dwellers. Gender \& Development, 3(2), 43-48.

Kovalchuk, V. (2015). Civic consciousness development of youth in the contex of educational refoms: the US experience. Comparative Professional Pedagogy, 5(2), 13 19.

Mohamadinejad, A., \& Mirsafian, H. (2015). Connection between the Legal Knowledge and Social Background of Sports Coaches at Iranian Universities. Iranian Studies, 48(4), 551-566.

Mujis, D. (2010). Doing quantitative research in education with SPSS. SAGE Publications.

Pashby, K., da Costa, M., Stein, S., \& Andreotti, V. (2020). A meta-review of typologies of global citizenship education. Comparative Education, 56(2), 144-164. https://doi.org/10.1080/03050068.2020.172 3352

Pevtsova, E. A., Sapogov, V. M., Timofeev, S. V., \& Knyazeva, E. Y. (2016). Ensuring human Rights and the Development of Legal Awareness of Juvenile Offenders in Closed Institutions. International Journal of Environmental and Science Education, 11(17), 10435-10444. 
Risdianto, E. (2018). Gambaran faktor-faktor yang mempengaruhi perilaku merokok terkait perilaku merokok pada siswa laki-laki di SMA Negeri 51 di Jakarta Timur Tahun 2017 (Doctoral dissertation, Universitas Binawan).

Rosamarlina, F. Y., \& Dianiati, K. S. (2010). Prevalens asma bronkial berdasarkan kuesioner ISAAC dan perilaku merokok pada siswa SLTP di daerah industri Jakarta Timur. Jurnal Respirator Indonesia, 30(3), 75-76.

Santos, C. E., Menjívar, C., VanDaalen, R. A., Kornienko, O., Updegraff, K. A., \& Cruz, S. (2017). Awareness of Arizona's immigration law SB1070 predicts classroom behavioural problems among Latino youths during early adolescence. Ethnic and Racial Studies, 1-19.

Sugiyono. (2013). Metode Penelitian Pendidikan Pendekatan Kuantitatif Kualitatif, dan R\&D.

Tagel, D. P. (2013). Kesadaran hukum masyarakat pengguna jalan di Kota Denpasar. Jurnal Magister Hukum Udayana, 2(2), 1-17.

Woods, B., \& Pratt, R. (2005). Awareness in dementia: Ethical and legal issues in relation to people with dementia. Aging and mental bealth, 9(5), 423-429.

Xinghua, G. (2009). Why Do We Obey the Law? Chinese Sociology and Anthropology, 41(2), 7-40. 